\title{
The Effect of Earning Management on Firm Value and Good Corporate Governance as a Moderating Variable
}

\author{
Sri Wahjuni Latifah ${ }^{1 *}$, Fina Novitasari ${ }^{2}$ \\ 1,2 University of Muhammadiyah Malang \\ "Corresponding author. Email: sriwahjuni@umm.ac.id
}

\begin{abstract}
This research aims to testing and proved the earnings management to the firm value by implementing Good Corporate Governance (GCG). The components of GCG include managerial ownership, institutional ownership, the size of the board of commissioners, the board of independent commissioners, and the audit committee. This research's object is a manufacturing corporation listed on the Indonesia Stock Exchange(SEC). These results indicate that an independent board of commissioners and an audit committee can moderate earnings management's effect on firm value with managerial ownership. Descriptive analysis results are the average value of managerial ownership is $23 \%$, an independent board of commissioners is $42 \%$, and an audit committee is $3 \%$.
\end{abstract}

Keywords: earnings management, firm value, good corporate governance

\section{INTRODUCTION}

The tight competition in the business or business world is currently a strong trigger for company management to show the best performance for the company they lead because the good or bad performance of the company will give an effect to company's market value and also affect investors to invest or withdraw their investment from a company. The financial report results from the company's operational activities and performance to be reported to internal and external parties with the parameter in the form of profit. Earnings information that is available in financial statements is the main requirement of investors in making decisions.

Earnings information is often the target of engineering through management's opportunistic actions to maximize their satisfaction because some of the parties pay more attention to earnings. It is realized by management, especially managers whose performance is measured based on earnings information. (Savitri, 2014). Therefore, earnings are often engineered to beautify financial reports known as earning management (Indracahya and Faisol, 2017). Earnings management practices have been carried out in many countries, including Indonesia (SUKARTHA, 2008). The information available in financial reports is an essential requirement for investors in making decisions (Widayanti et al., 2014).

The selection of accounting policies is shown so that the company can increase or decrease the profits obtained following the needs and desires of management so that the company's financial statements look good in users' eyes. Sometimes these actions are contrary to the main principles in the company. Such management behavior is known as earning management. (Agustia and Suryani, 2018).

On the contrary, The agent now knows more about their capacity, workplace, and overall company.(Anggraeni and Hadiprajitno, 2013). Agency theory (Jensen and Meckling, 1976), (Sunarto, 2009) is a theory that explains the existence of two individuals, namely agents or managers who carry out the duties of the principal or capital owner in maximizing company results.

Several factors that can be used as indicators to minimize earnings management are by doing GCG. GCG itself is an effort that can be made by all parties to direct or control the company in order to achieve company balance. So, corporate value can be increased by implementing GCG (Ferial and Handayani, 2016). GCG implementation mechanisms include managerial 
ownership, ownership structure, board members, a board of independent commissioners, and an audit committee. Based on (Dwija, 2012), the concept of GCG, is a tool to give investors confidence that they will receive a return on their invested funds.

Several previous research results state that companies can reduce information asymmetry by improving financial reporting quality (Biddle et al., 2009). The impact of earnings management on firm value was investigated by (Herawaty, 2008) who found that earnings management positively influences firm value. (Darwis, 2012) proves that earnings management does not affect firm value; it means that managers' earnings management actions will not influence firm value. Besides, (Shen et al., 2015) proves that companies in China that carry out earnings management positively affect overinvestment. It means that earnings management is negatively related to investment efficiency. A sample of companies in ASEAN (erial and Handayani, 2016) proves that the financial reporting quality negatively impacts underinvestment, but it has no effect on overinvestment.

From some of the explanations above, it can be concluded that this study is critical because the previous studies regarding Based on some of the primary justifications, it is reasonable to conclude that this research is essential because prior studies on the impact of earnings management on firm value have yielded inconsistent results. As a result, the researcher wishes to review this research by connecting the role of GCG, which consists of managerial ownership, institutional ownership, the size of the board of commissioners, and the size of the board of commissioner, and the audit committee, which are intended to reduce the prospect of earnings practices, which nowadays often occur within the scope of companies carried out by company management.

\section{LITERATURE REVIEW}

\subsection{The Effect of Earnings Management on Firm Value with GCG as a Moderating Variable}

The agency theory perspective occurs when there are differences in interests between principals and agents who tend to be selfish in allocating investment sources. (Darwis, 2012). Compared to the owners (shareholders), the manager of a company has the advantage of knowing more about the company's internal information and prospects, resulting in asymmetric information. Because of the information asymmetry among management and owners, managers can perform earnings management so the firm value at a particular time will increase to mislead owners (shareholders) regarding the actual value of the company.
The results of previous research conducted (Wiralestari and Fitriyani, 2012) proved that the independent commissioner and audit committee variables as proxies of GCG positively affect earnings management. Therefore, based on the theory's description and previous research, the proposed hypothesis is:

H-1: Managerial ownership, institutional ownership, size of the board of commissioners, the board of independent commissioners, and the audit committee can moderate the effect of earnings management on firm value.

Figure 1. Theoretical Framework

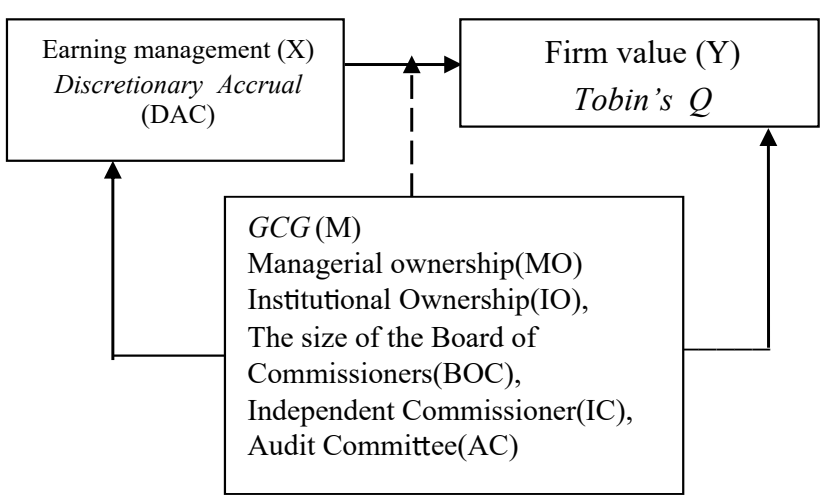

\section{RESEARCH METHOD}

The sampling method is using purposive sampling method, with the following criteria: (1) It is a manufacturing company that listing on the IDX for the 2018 period, (2) The company has audited financial reports that ended on December 31 and were published in 2018, (3) The company's financial statements report in rupiah currency during the observation period in 2018, (4) The company has data that related to the variables needed for the 2018 research period. So that companies that meet the criteria are 60 companies.

Variable and measurements:

Earning Management : $D A_{i t}=\left(T A_{i t}-T A_{i t-1}\right) / A_{i t-1}$ Firm Value: Tobin's $Q=Q=\left(\frac{E M V+D}{E B V+D}\right)$

GCG:

Managerial ownership:

$$
\begin{aligned}
& K M=\frac{\text { number of shares owned by management }}{\text { number of shares outstanding }} \\
& \times 100 \%
\end{aligned}
$$

Institutional ownership :

$$
\begin{gathered}
\text { INS }=\frac{\text { number of shares owned by the institution }}{\text { number of shares outstanding }} \\
\quad \times 100 \%
\end{gathered}
$$

Size of the Board of Commissioners: 
DK $=$ Total members of the company's board of commissioners

Independent board of commissioners:

$$
D K
$$

$$
\begin{aligned}
& =\frac{\text { number of independent board of com }}{\text { total member of the company' sboard of com }} \\
& \times 100 \%
\end{aligned}
$$

Audit Committee:

$\mathrm{KA}=$ The entire number of existing audit members

This research uses secondary data types, namely quantitative data sourced from the company's annual financial reports of manufacturing companies listed on the Indonesia Stock Exchange (IDX) in 2018. This research data was obtained by accessing the IDX's official website (www.idx.co.id). This study's data analysis technique consisted of four stages, namely, by conducting a descriptive analysis. Furthermore, performing a classical assumption test with several tests: the normality test, the multicollinearity test, the heteroscedasticity test, and the autocorrelation test. It was then continued with the Moderated Regression Analysis (MRA) test. If analysis requirements through the classical assumption test. Later, the hypothesis testing is the partial $t$ statistical test and the simultaneous $\mathrm{F}$ statistical test, which can be done based on calculations from Moderated Regression Analysis (MRA), which is carried out using SPSS.

\section{RESULTS AND DISCUSSION}

\subsection{Descriptive Data}

\begin{tabular}{|c|c|c|c|c|c|}
\hline & $\mathrm{N}$ & Minimum & $\begin{array}{c}\text { Maximu } \\
\mathrm{m}\end{array}$ & Mean & $\begin{array}{c}\text { Std. } \\
\text { Deviatio } \\
\mathrm{n}\end{array}$ \\
\hline TOBINS'Q & 60 & .197 & .773 & .42730 & .127578 \\
\hline DAC & 60 & .010 & .606 & 10912 & .103689 \\
\hline KM & 60 & .016 & .558 & .23988 & 138989 \\
\hline INST & 60 & .131 & .898 & .64188 & .192750 \\
\hline DK & 60 & 2.000 & 10.000 & $\begin{array}{r}3.7000 \\
0\end{array}$ & $\begin{array}{r}1.69045 \\
2\end{array}$ \\
\hline DKI & 60 & .050 & .667 & .42190 & .106747 \\
\hline KA & 60 & 3.000 & 4.000 & $\begin{array}{r}3.0333 \\
3\end{array}$ & .181020 \\
\hline $\begin{array}{l}\text { Valid N } \\
\text { (listwise) }\end{array}$ & 60 & & & & \\
\hline
\end{tabular}

Results of descriptive statistical analysis can be seen through the following explanation:

Table 1. Descriptive Statistics Test
Table 1 point out that the average of firm value is 0.42730 and the standard deviation is 0.127578 . It means that the company value has a low score. Based on the interpretation of Tobin's Q score, it states that Tobin's Q $<1$. The average of earnings management variable is 0.10912 and the standard deviation is 0.103689 . It means that companies tend to do income increasing or increase profits. The average managerial ownership variable is 0.23988 , and the standard deviation is 0.138989 . It means that the average managerial ownership is above $20 \%$. The average institutional ownership variable is 0.64188 and the standard deviation is 0.192750 . It means that the average institutional ownership is above $20 \%$. The average of the board of commissioners' size is 3,70000 and the standard deviation is 1.690452 . As a result, the greater the number of board members, the easier it will be to control the CEO and the more influential the monitoring will be. The independent board of commissioners' variable average has an is 0.41470 and the standard deviation is 0.097125 . OJK regulation, no. 33 / PJOK. 04/2014 stating that the number of independent commissioners is not less than $30 \%$ of the board of commissioners' total members. The average audit committee variable has an average value of 3.033, with the standard deviation being 0.181020. The companies are included in the sample of this study are following the requirements of the audit committee members, namely three people.

\subsection{Normality Test}

Based on (Ghozali, 2016), the regression model is normally distributed if the probability $>0.05$. The following is a picture of the normality test.

Table 2. Normality Test

One-Sample Kolmogorov-Smirnov Test

Unstandardized Residual

$\mathrm{N}$ 60

Normal Mean $\quad 0000000$

Parameters $^{\mathrm{a}, \mathrm{b}}$ Std. Deviation $\quad .10208445$

Most Extreme Absolute $\quad .071$

Differences Positive .042

\begin{tabular}{ll} 
Negative & -.071 \\
\hline
\end{tabular}

Test Statistic $\quad .071$

Asymp. Sig. (2-tailed) $\quad .200$

Source: SPSS output processed, 2019

Table 2 above shows that the Kolmogorov Smirnov test results show that data obtained is 0.200 . These results indicate that the probability $>0.05$. 


\subsection{Multicollinearity Test}

Based on (Ghozali, 2016) the Variance Inflation Factor (VIF) value of each independent variable on the dependent variable can be used to detect the presence or absence of multicollinearity. If the VIF value is less than 10 and the tolerance value is greater than 0.01 , the model is said to be free of multicollinearity symptoms. Fiurthermore, the VIF value is less than 10 , and the tolerance value is greater than 0.01 . As a result, it is possible to conclude that there is no multicollinearity.

\subsection{Heteroscedasticity Test}

Based on (Ghozali, 2016) ,criteria for heteroscedasticity testing with the Scatter Plot states that if the residual points are randomly spread out, then the heteroscedasticity test is fulfilled. So, the results of the heteroscedasticity test is:

Table 3. heteroscedasticity test

\begin{tabular}{|c|c|c|c|c|}
\hline \multirow[b]{2}{*}{ Model } & \multicolumn{2}{|c|}{$\begin{array}{l}\text { Unstandardized } \\
\text { Coefficients }\end{array}$} & \multicolumn{2}{|c|}{$\begin{array}{l}\text { Collinearity } \\
\text { Statistics } \\
\text { oleranc }\end{array}$} \\
\hline & $\mathrm{B}$ & Std. Error & $\mathrm{e}$ & VIF \\
\hline $\begin{array}{l}1 \text { (Constant } \\
\text { ) }\end{array}$ & 1.572 & .353 & & \\
\hline DAC & .035 & .158 & .916 & 1.091 \\
\hline KM & -.277 & .126 & .797 & 1.255 \\
\hline INST & -.189 & .089 & .830 & 1.205 \\
\hline DK & -.007 & .010 & .781 & 1.280 \\
\hline DKI & -.181 & .161 & .833 & 1.201 \\
\hline KA & -.283 & .104 & .692 & 1.446 \\
\hline
\end{tabular}

Table 4. Scatter plot test

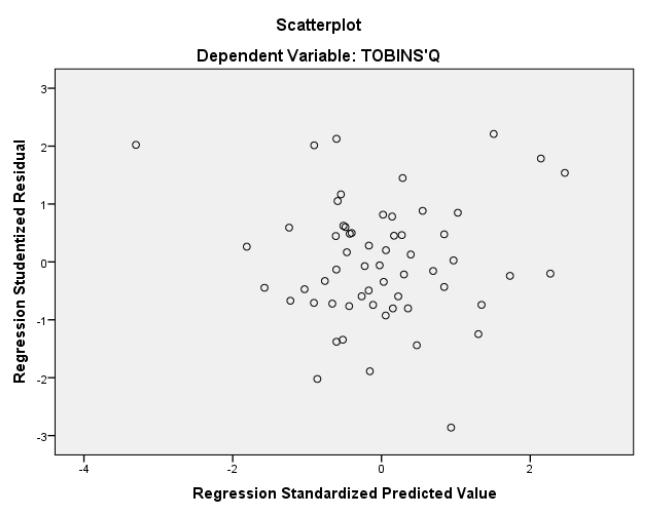

Source: SPSS output processed, 2019
Table 4 shows that the residual points spread randomly, so it can be stated that the heteroscedasticity test is fulfilled, and there are no heteroscedasticity symptoms.

\subsection{Autocorrelation Test}

Based on (Ghozali, 2016) The criteria for autocorrelation testing using the Run Test are if the Asymp. Sig value is $<0.05$. Then there are autocorrelation symptoms. And if the Asymp.Sig value is> 0.05. There are no autocorrelation symptoms. The Run Test results are shown in the table below.

Table 5. The Run Test

\begin{tabular}{lr}
\hline \multicolumn{2}{c}{ Runs Test } \\
\hline & $\begin{array}{c}\text { Unstandardized } \\
\text { Residual }\end{array}$ \\
\hline Test Value & -.00723 \\
\hline Cases $<$ Test Value & 30 \\
\hline Cases $>=$ Test Value & 30 \\
\hline Total Cases & 60 \\
\hline Number of Runs & 33 \\
\hline Z & .521 \\
\hline Asymp. Sig. (2-tailed) & .602 \\
\hline
\end{tabular}

Table 5 shows that the Run Test test indicates that the Asymp.Sig value is 0.602. It means that Asymp.Sig> than 0.05 . So, it can be concluded that there are no autocorrelation symptoms.

\subsection{Moderated Regression Analysis (MRA) Test}

The Moderated Regression Analysis (MRA) test is a subset of multiple linear regression. This regression equation contains an interaction element, namely the multiplication of two or more independent variables, strengthening or weakening the relationship between the independent and dependent variables. The following are the results of the Moderated Regression Analysis (MRA) test: 
Table 6. MRA Regression Test

\begin{tabular}{|c|c|c|c|c|c|}
\hline & \multicolumn{5}{|c|}{ Standardized } \\
\hline & Unstandardized & Coefficients & Coefficients & $T$ & $\mathrm{Sig}$ \\
\hline onstant) & 1.373 & 368 & & 3.736 & .000 \\
\hline .C & -.874 & 2.756 & -.711 & -.317 & .752 \\
\hline 1 & 1.993 & 1.565 & .617 & 1.274 & .209 \\
\hline IT & -.211 & .124 & -.318 & -1.700 & .096 \\
\hline : & -.015 & .021 & -.199 & -.705 & .484 \\
\hline I & .290 & .258 & .243 & 1.125 & .266 \\
\hline . & .658 & .783 & 1.613 & .840 & .405 \\
\hline ، $\mathrm{C}^{*} \mathrm{KM}$ & -.519 & .187 & -.566 & -2.778 & .008 \\
\hline ، $C *$ INST & -.250 & 1.291 & -.130 & -.194 & .847 \\
\hline .C*DK & .110 & .244 & .309 & .452 & .653 \\
\hline .C*DKI & -4.300 & 2.103 & -1.619 & -2.045 & .046 \\
\hline C. ${ }^{*} \mathrm{KA}$ & -.249 & .113 & -.354 & -2.212 & .032 \\
\hline
\end{tabular}

Source: SPSS output processed, 2019

Table 6 shows the results of the Moderated Regression Analysis (MRA) Test. A regression equation can be drawn up as follows:

1. $\mathrm{Y}=1,373+-0,874 X_{1}+1,993 X_{2}+-0,519 X_{1} X_{2}$

2. $\mathrm{Y}=1,373+-0,874 X_{1}+-0,211 X_{3}+$

$-0.250 X_{1} X_{3}$

3. $\mathrm{Y}=1,373+-0,874 X_{1}+-0,15 X_{4}+0,110 X_{1} X_{4}$

4. $\mathrm{Y}=1,373+-0,874 X_{1}+0,290 X_{5}+-4,300 X_{1} X_{5}$

5. $\mathrm{Y}=1,373+-0,874 X_{1}+0,658 X_{6}+-0,249 X_{1} X_{6}$

The conclusion drawn from the estimated regression results is that managerial ownership, an independent board of commissioners, and an audit committee, as moderating factors, can strengthen or weaken the impact of earnings management on firm value.

\subsection{Determination Coefficient Test}

The coefficient of determination test assesses the model's ability to explain variation in the dependent variable. The results of the determination coefficient test are shown in the table below:

Table 7. Regression Coefficient Test

Summary Model

\begin{tabular}{|c|c|c|c|c|}
\hline del & $\mathrm{R}$ & R Square & Adjusted R Square & Std. Error of the Estir \\
\hline & $.600^{\mathrm{a}}$ & .360 & .213 & .1 \\
\hline
\end{tabular}

Table 7 illustrates the R Square is 0.360 or $36 \%$. It means that the contribution of earnings management and GCG to firm value is $36 \%$.

\subsection{T-Partial Test}

Based on (Ghozali, 2016) the criteria for this partial significance test are that if the probability is 0.05 , it indicates that the independent variable $(\mathrm{X})$ has a partial effect on the dependent variable (Y). The following table is the results of the partial significance test:
Table 8. Partial T-test

\begin{tabular}{|c|c|c|c|c|c|}
\hline \multirow[b]{2}{*}{ Model } & \multicolumn{2}{|c|}{ Unstandardized Coefficients } & \multirow{2}{*}{$\begin{array}{c}\text { Standardized } \\
\text { Coefficients } \\
\text { Beta }\end{array}$} & \multirow[b]{2}{*}{$\mathrm{T}$} & \multirow[b]{2}{*}{ Sig. } \\
\hline & B & Std. Error & & & \\
\hline 1 (Constant) & 1.373 & .368 & & 3.736 & .000 \\
\hline DAC & -.874 & 2.756 & -.711 & -.317 & .752 \\
\hline KM & 1.993 & 1.565 & .617 & 1.274 & .209 \\
\hline INST & -.211 & .124 & -.318 & -1.700 & .096 \\
\hline DK & -.015 & .021 & -.199 & -.705 & .484 \\
\hline DKI & .290 & .258 & .243 & 1.125 & .266 \\
\hline KA & .658 & .783 & 1.613 & .840 & .405 \\
\hline $\mathrm{DAC} * \mathrm{KM}$ & -.519 & .187 & -.566 & -2.778 & .008 \\
\hline DAC*INST & -.250 & 1.291 & -.130 & -.194 & .847 \\
\hline $\mathrm{DAC} * \mathrm{DK}$ & .110 & .244 & .309 & .452 & .653 \\
\hline DAC*DKI & -4.300 & 2.103 & -1.619 & -2.045 & .046 \\
\hline $\mathrm{DAC} * \mathrm{KA}$ & -.249 & .113 & -.354 & -2.212 & .032 \\
\hline
\end{tabular}

Table 8 above shows that the level of significance between earnings management on firm value and managerial ownership as a moderating variable results in 0.008 less than 0.05 . It shows an interaction effect between earnings management variabel and managerial ownership variables on firm value. Level of significance between earnings management variable on firm value with institutional ownership as a moderating variable is 0.847 , greater than 0.05 . It indicates that there is no interaction effect between earnings management and institutional ownership on firm value. The level of significance between the earnings management variable on firm value and the board of commissioners' size as a moderating variable is 0.653 , greater than 0.05 . It shows that earnings management is not affecting the size of the board of commissioners on firm value. Level of significance between earnings management on firm value with the independent board of commissioners as a moderating variable is 0.046 less than 0.05 . It shows an interaction effect between earnings management and the independent board of commissioners on firm value. The level of significance between earnings management on firm value with the audit committee as a moderating variable is 0.032 less than 0.05 . It shows an influence of the interaction between earnings management and the audit committee on firm value.

\subsection{F-Simultaneous Test}

Based on (Ghozali, 2016) The criteria for this simultaneous $\mathrm{f}$ test is if the probability $<0.05$, it means that the independent variable $(\mathrm{X})$ is simultaneously affecting the dependent variable (Y). The following are the results of the simultaneous $\mathrm{f}$ test: 
Table 9. F-Test

\begin{tabular}{lrrrrr}
\hline \multicolumn{7}{c}{ ANOVA $^{\mathrm{a}}$} \\
\hline Model & Sum of Squares & \multicolumn{1}{c}{ Df } & Mean Square & F & Sig. \\
\hline 1 Regression & .345 & 11 & .031 & 2.452 & $.016^{\mathrm{b}}$ \\
Residual & .615 & 48 & .013 & & \\
Total & .960 & 59 & & & \\
\hline
\end{tabular}

Source: SPSS output processed, 2019

From table 9 above, it can be seen that the significance value of 0.016 is under 0.05 . So, the conclusion is simultaneous earnings management moderated by managerial ownership, institutional ownership, size of the board of commissioners, the independent board of commissioners, and the audit committee significantly affecting firm value.

\section{DISCUSSION}

\subsection{Effect of Earnings Management on Firm Value with MO as a Moderating Variable}

This research's result shows that managerial ownership can moderate the effect of earnings management on firm value. Thus, the first hypothesis, which states that managerial ownership can moderate the effect of earnings management on firm value, is accepted. The explanation related to this is based on evidence from descriptive analysis results by producing an average managerial ownership value of $23 \%$, meaning that managerial ownership can control the company's internal. It shows that managerial ownership can control the company in increasing firm value. This reseach's results are inconsistent with the previous studies conducted by (Darwis, 2012) which state that managerial ownership cannot moderate the impact of earnings management on firm value.

\subsection{Effect of Earnings Management on Firm Value with IO as a Moderating Variable}

Based on this research's results, it states that institutional ownership cannot moderate the effect of earnings management on firm value. The first hypothesis states that institutional ownership can moderate earnings management's effect on firm value is rejected. The explanation related to this is based on evidence from the descriptive analysis test results with an average value of $64 \%$ of institutional ownership. In this study, institutional ownership has a high percentage but cannot reduce earnings management actions on firm value. This research's results are consistent with previous research from (Wiralestari and Fitriyani, 2012) which proves that institutional ownership cannot moderate the relations between earnings management variables on firm value.

\subsection{Effect of Earnings Management on Firm Value with BOC Size as a Moderating Variable}

Based on the findings of this study, it is concluded that the board of commissioners' size is incapable of moderating the effect of earnings management on firm value. As a result, the first hypothesis, which states that the board of commissioners' size is incapable of moderating the effect of earnings management on firm value, is denied. Explanation related to this is based on evidence from the descriptive analysis test results with an average value of the board of commissioners of $3 \%$, meaning that a small number of commissioners in a company cannot monitor the performance of the directors to be run. This study's results are consistent with previous research from (Handayani et al., 2016), which states that since the formation of the commissioners' formation is only from applicable regulations. This study's results are also consistent with (Hijriani et al., 2017), stating that the average board attendance rate does not affect tax avoidance.

\subsection{Effect of Earnings Management on Firm Value with the IC as a Moderating Variable}

This research's results that have been done, states that the independent board of commissioners can moderate the impact of earnings management on firm value. So, the first hypothesis stating that the independent board of commissioners can moderate the effect of earnings management on firm value is accepted. The explanation related to this is based on the descriptive analysis test results with an average value of the independent board of commissioners of $42 \%$. This results shows that the independent board of commissioners has more power than board of commissioners. The study results are inconsistent with previous studies from (Ridwan and Gunardi, 2014), stating that the independent board of commissioners is not a variable that can moderate the effect of earnings management on firm value. Meanwhile, research of (Limantauw, 2012) states that the higher the proportion of independent commissioners to the total number of commissioners, then the level of accounting conservatism being measured is also more significant.

\subsection{Effect of Earnings Management on Firm Value with the AC as a Moderating Variable}

Based on research's results, it is stated that the audit committee can moderate the effect of earnings management on firm value. Thus the first hypothesis states that the audit committee can moderate the effect of earnings management on firm value is accepted. The explanation related to this is based on the descriptive analysis test results with the average value of the three (3) audit committee's average value. It shows that the company included in the research sample has three audit 
committee members and according to the audit committee's criteria. This study's results are consistent with previous research form (Wiralestari and Fitriyani, 2012), which states that a company's audit committee can influence management to carry out real earnings management activities.

\section{CONCLUSIONS}

This research is using manufacturing companies that listing on the Indonesia Stock Exchange. Based on the results of analysis data and discussion that has been carried out, the conclusion is GCG with Managerial Ownership (KM) indicators, the Independent Board of Commissioners (DKI), and the Audit Committee (KA) moderates the effect of Earning Management on Firm Value. This is because the percentage of shares that owned by the company is high, the percentage of independent commissioners is high, and the number of audit members who are fit with the criteria of the audit committee. However, Institutional Ownership (INST) and Size of the Board of Commissioners (DK) do not moderate the effect between Earning Management on Firm Value. This is due to the low percentage of institutional ownership and the small number of commissioners.

This study's limitation is the existence of outlier data so that the data is deleted and cannot be examined optimally. There are many large-scale manufacturing companies, which means that they have high financial capacity compared to small-scale manufacturing companies, so that the resulting data varies. Also, this study's limitation is that earnings management's measurement does not pay attention to fair value measurement.

\subsection{Suggestion}

The suggestions are further researchers can increase the number of periods, the number of company samples, and try to use other moderating variables or add components of GCG to determine which are variables that also can moderate the influence of management profit against firm value. This study's results can be a management consideration in adding to the board of commissioners because it is still within the minimum limit, and the board of commissioners's role needs to be improved in supervising so that the applied earnings management does not violate the law.

\section{REFERENCES}

[1]. Agustia, Y. P., dan E. Suryani. 2018. "Pengaruh Ukuran Perusahaan, Umur Perusahaan, Leverage, Dan Profitabilitas Terhadap Manajemen Laba (Studi Pada Perusahaan Pertambangan yang Terdaftar di Bursa Efek Indonesia Periode 2014-2016)". Jurnal ASET (Akuntansi Riset), Vol. 10, No. 1, hlm: 71-82.

[2]. Anggraeni, R. M., dan B. Hadiprajitno. 2013. "Pengaruh Struktur Kepemilikan Manajerial, Ukuran Perusahaan, dan Praktik Corporate Governance terhadap Manajemen Laba". Diponegoro Journal of Accounting, Vol., No., hlm: 754-766.

[3]. Biddle, G. C., G. Hilary, dan R. S. Verdi. 2009. "How does financial reporting quality relate to investment efficiency?". Journal of accounting and economics, Vol. 48, No. 2-3, hlm: 112131.

[4]. Darwis, H. 2012. "Manajemen laba terhadap nilai perusahaan dengan corporate governance sebagai pemoderasi". Jurnal keuangan dan Perbankan, Vol. 16, No. 1, hlm.

[5]. Dwija, I. G. A. M. A. 2012. "Pengaruh Kebijakan Dividen dan Good Corporate Governance terhadap Manajemen Laba". Buletin Studi Ekonomi, Vol., No., hlm.

[6]. Ferial, F., dan S. R. Handayani. 2016. "Pengaruh Good Corporate Governance Terhadap Kinerja Keuangan Dan Efeknya Terhadap Nilai Perusahaan (Studi Pada Badan Usaha Milik Negara Yang Terdaftar Di Bursa Efek Indonesia Periode 2012-2014)". Jurnal Administrasi Bisnis, Vol. 33, No. 1, hlm: 146153.

[7]. Ghozali, I. 2016. "Aplikasi Analisis Multivariete dengan Program IBM SPSS 23, Edisi Delapan". Penerbit Universitas Diponogoro. Semarang, Vol., No., hlm.

[8]. Handayani, U. T., S. V. Siregar, dan E. Tresnaningsih. 2016. "Kualitas pelaporan keuangan, mekanisme governance, dan efisiensi investasi". Jurnal Akuntansi Multiparadigma, Vol. 7, No. 2, hlm: 270-287.

[9]. Herawaty, V. 2008. "Peran praktek corporate governance sebagai moderating variable dari pengaruh earnings management terhadap nilai perusahaan". Jurnal akuntansi dan keuangan, Vol. 10, No. 2, hlm: 97-108.

[10]. Hijriani, A. N., S. W. Latifah, dan S. Setyawan. 2017. "Pengaruh Koneksi Politik, 
Dewan Komisaris dan Karakteristik Perusahaan terhadap Penghindaran Pajak (Perusahaan BUMN Yang Terdaftar di Bursa Efek Indonesia)". Jurnal Reviu Akuntansi dan Keuangan, Vol. 4, No. 1, hlm.

[11]. Indracahya, E., dan D. A. Faisol. 2017. "The Effect of Good Corporate Governance Elements, Leverage, Firm Age, Company Size and Profitability on Earning Management (Empirical Study of Manufacturing Companies in Bei 2014-2016)". Profita, Vol. 10, No. 2, hlm: 203-227.

[12]. Jensen, M. C., dan W. H. Meckling. 1976. "Theory of the firm: Managerial behavior, agency costs and ownership structure". Journal of financial economics, Vol. 3, No. 4, hlm: 305-360.

[13]. Limantauw, S. 2012. "Pengaruh karakteristik dewan komisaris sebagai mekanisme good Corporate govenance terhadap tingkat konservatisme akuntansi Pada perusahaan manufaktur yang terdaftar di BEI". Jurnal Ilmiah Mahasiswa Akuntansi, Vol. 1, No. 1, hlm: 48-52.

[14]. Ridwan, M., dan A. Gunardi. 2014. "Peran Mekanisme Corporate Governance sebagai Pemoderasi Praktik Earning Management terhadap Nilai Perusahaan". Trikonomika Journal, Vol. 12, No. 1, hlm: 4960.

[15]. Savitri, E. 2014. "Analisis Pengaruh Leverage Dan Siklus Hidup Terhadap Manajemen Laba Pada Perusahaan Real Estate Dan Property Yang Terdaftar Di Bursa Efek Indonesia". Jurnal Akuntansi, Vol. 3, No. 1, hlm: 72-89.

[16]. Shen, C.-H., F. Luo, dan D. Huang. 2015. "Analysis of earnings management influence on the investment efficiency of listed Chinese companies". Journal of Empirical Finance, Vol. 34, No., hlm: 60-78.

[17]. Sukartha, I. M. 2008. "Pengaruh Manajemen Laba, dan Kepemilikan Manajerial pada Kesejahteraan Pemegang Saham Perusahaan Target Akuisisi". Jurnal Ilmiah Akuntansi dan Bisnis, Vol., No., hlm.

[18]. Sunarto, S. 2009. "Teori Keagenan dan Manajemen Laba". Jurnal Ilmiah Kajian Akuntansi, Vol. 1, No. 1, hlm: 13-28.

[19]. Widayanti, C. A., M. Vestari, dan D. N. Farida. 2014. "Faktor-faktor yang mempengaruhi kualitas laba pada perusahaan high profile yang terdaftar di BEI". Jurnal Dinamika Ekonomi \& Bisnis, Vol. 11, No. 1, hlm.

[20]. Wiralestari, W. T., dan D. Fitriyani. 2012. "Analisis Pengaruh Komisaris Independen, Komite Audit dan Kepemilikan Institusional terhadap Manajemen Laba". Jurnal Penelitian Universitas Jambi: Seri Humaniora, Vol. 14, No. 1, hlm. 